\title{
Prenatal care in a primary healthcare center for imprisoned pregnant women
}

\author{
Pré-natal em unidade básica de saúde a gestantes em situação prisional \\ Prenatal en unidad básica de salud a embarazadas en situación carcelaria
}

Maria do Carmo Silva Fochi ${ }^{1}$, Agnês Raquel Camisão da Silva ${ }^{1}$, Maria Helena Baena de Moraes Lopes ${ }^{1}$

This experience report aimed to describe the prenatal care undertaken in a primary care center in the non-metropolitan area of the State of São Paulo, Brazil, offered to the female prison population. The data and related information refer to the period June 2010 - June 2012. The article describes the construction of the work process by the local team, the dynamics of providing the attendance, the human resources involved and the consultations undertaken. The prenatal care provided to the pregnant women made it possible to investigate the pluralized universe of imprisoned women and their needs resulting from the condition of being pregnant in the prison environment. Thus, decent attendance to the prison population's health a human and constitutional right - is considered important, so as to avoid physical, emotional and social problems, which in the pregnant woman may be passed on to her child.

Descriptors: Primary Health Care; Prenatal Care; Women's Health; Pregnant Women; Prisons.

Objetivou-se descrever a assistência pré-natal realizada em uma unidade básica de saúde do interior do estado de São Paulo, Brasil, e ofertada à população carcerária feminina. Trata-se de um relato de experiência. Os dados e informações relatadas referem-se ao período de junho de 2010 a junho de 2012. São descritos a construção do processo de trabalho pela equipe local, a dinâmica do atendimento, os recursos humanos envolvidos e consultas realizadas. A assistência pré-natal oferecida às gestantes permitiu conhecer o universo pluralizado da mulher presidiária e suas necessidades decorrentes da condição de ser gestante em ambiente prisional. Assim, considera-se importante o atendimento digno à saúde da população carcerária, direito humano e constitucional, para evitar agravos físicos, emocionais e sociais, que na gestante, pode se estender à sua prole.

Descritores: Atenção Primária à Saúde; Cuidado Pré-Natal; Saúde da Mulher; Gestantes; Prisões.

El objetivo fue relatar la atención prenatal realizada en unidad básica de salud del interior de São Paulo, Brasil, a población carcelaria femenina. Se trata de un relato de experiencia. Datos e informaciones referidas al período de junio de 2010 a junio de 2012. Son descriptas la construcción del proceso de trabajo por parte del equipo local, la dinámica de atención, los recursos humanos involucrados y las consultas realizadas. La atención prenatal ofrecida a las embarazadas permitió conocer el universo pluralizado de la mujer presidiaria y sus necesidades derivadas de su condición de embarazada en ámbito carcelario. Así, se considera la importancia de atención digna de salud a la población carcelaria, derecho humano y constitucional, para evitar padecimientos físicos, emocionales y sociales que, en la embarazada, pueden extenderse a su prole.

Descriptores: Atención Primaria de Salud; Atención Prenatal; Salud de la Mujer; Mujeres Embarazadas; Prisiones.

\footnotetext{
${ }^{1}$ Universidade Estadual de Campinas. Campinas, SP, Brazil.

Corresponding author: Maria do Carmo Silva Fochi

Alameda Pitangueira, 82, Lagoa Bonita, Engenheiro Coelho, SP, Brazil CEP: 13165000. E-mail: mcfochi@gmail.com
} 


\section{Introduction}

Pregnancy is a period of many physical, psychological and social changes for women, requiring them to make adaptations, whose social and cultural factors will determine each person's responses in the experience of the process of pregnancy ${ }^{(1)}$. Considering the prison population to be a vulnerable group, maternal and child health care in these circumstances should be prioritized. Women in prison may be exposed to physical and mental illnesses and - when pregnant - may be subject to a lack of appropriate care which will influence the development and result of the pregnancy. The various changes which occur during pregnancy, whose responses depend on factors such as family relationships, socio-economic environment, religion and others, make it necessary to offer qualified and humanized prenatal care, integrating the promotion of the pregnant woman's health, the provision of health care for her, and the prevention of threats to her health ${ }^{(2)}$. For a pregnant woman in prison, feelings of fear, insecurity and distress may be exacerbated; and in this context, the prenatal care must offer care and conducts which benefit the pregnant woman and her unborn child ${ }^{(3)}$.

Due to the inmates' heterogeneity, the prison environment offers physical and psychological risks, added to, above all, by the transmission of infectious diseases. There is an increase in vulnerability to infection by HIV and other illnesses, such as tuberculosis, also increasing the rates of HIV-related morbidity and mortality, which is attributed to the poor quality of the physical conditions in the prisons and jails, to the lack of spaces, and to the absolute unhealthiness in the prison units ${ }^{(4)}$.

In the prison environment, one can observe a high prevalence of mental disorders and comorbidities, above the rates of the population in general. One Brazilian study shows that prisoners are more prone to present mental illnesses, requiring mental treatment and the use of psychotropic medications. Prison is known for causing psychological consequences in women, contributing to self-destructive behaviors in women's prisons. This scenario points to the need for multidisciplinary attention in the monitoring of the health of women in prison situations ${ }^{(5)}$.

Although prison should have a transformative character for the individual, through the social isolation, the work and the corrective techniques used, these measures have been inefficacious and, for the female population, often, have replicated in the prison the history of violence experienced throughout their lives ${ }^{(6)}$.

Due to the shortage of resources, however, governments claim the Principle of Possible Reserve to be a factor impeding the right to health from being implemented for the individual in prison as much as for the population in general, thus placing limits for the implementation of fundamental rights. As no right is absolute, here only the legal norms regarding health are discussed. The tensions existing in the health field regarding the relationship between health and rights are numerous and growing, awakening the search for decent health and life ${ }^{(7)}$.

Health, however, is considered a basic right which must be made available equitably for every citizen, such that we may have a healthy society ${ }^{(8-7)}$. The 1988 Brazilian Constitution, in the terms of article 196, considers health to be a right of all and a duty of the State, which must be ensured through social and economic policies. Due to these considerations, the Unified Health System (SUS, in Portuguese)) is based on the doctrinal principles of universality, equality, and comprehensiveness ${ }^{(9)}$.

Primary care is characterized by a set of health actions, in the individual and collective ambit, encompassing the promotion and the protection of health, the prevention of harm to health, and the diagnosis, treatment, rehabilitation and maintenance of health, regulated through the National Plan for Primary Healthcare (PNAB, in Portuguese) ${ }^{(10)}$.

The prison population is categorized as dependent on the Unified Health System, care for this population being guaranteed under the National 
Plan on Health in the Prison System, through Interministerial Ordinance N. 1777 of 09/09/2003, in a partnership between the Ministry of Health and Ministry of Justice. The National Plan on Health in the Prison System establishes directives related to the prevention of health problems and the provision of health care for persons deprived of their liberty, reinforcing the prevention, diagnosis and care in prison environments, with emphasis on improvement of the services provided for the prison population, in particular that provided by the professionals of the health teams and by the prison staff ${ }^{(11)}$.

In June 2012, according to the National Penitentiary Department (DEPEN, in Portuguese), the prison population was estimated at 549,577 detainees in Brazil, of whom 190,818 were in the State of São Paulo (SP), demonstrating that this State holds 30\% of the national prison population, with 12,346 women $^{(12)}$. The imprisoned female population, therefore, has a large contingent requiring specific assistance to their needs, principally when they experience pregnancy.

Considering these considerations, the present article aims to report the prenatal care undertaken in a primary healthcare center in the nonmetropolitan area of the state of SP, which has within its territory a female penitentiary, with approximately 1200 women, to whom it offers healthcare with a focus on prenatal monitoring, as well as gynecological assistance in serious cases, according to the risk evaluation and prioritization by the penitentiary health team, thus sharing the local resources.

\section{Method}

This is an experience report of a primary healthcare center (UBS, in Portuguese) in the nonmetropolitan area of the State of São Paulo which, in addition to its routine activities, attends a prison population of approximately 1200 women and undertakes approximately 20 prenatal consultations per month. The data and information refer to the period June 2010 - June 2012.
The UBS in question serves a population of approximately 45,000 inhabitants, according to the Brazilian Institute of Geography and Statistics (IBGE, in Portuguese) in the 2010 survey. The center is organized with four specialist teams, a mental health team and an oral health team ${ }^{(13)}$.

The municipality works with a broadened model of the Family Health Strategy, which included in its teams specialists such as pediatricians, gynecologists and dentists, as well as organizational innovations, so as to alter the traditional doctor-centered model. This model, termed the Paideia Method, seeks to improve persons and institutions, and has organizational democracy as a basis. Its objective is to increase the collectives' ability for analysis and intervention ${ }^{(14)}$.

The team responsible for the area of the prison is made up of one doctor (a general practitioner); a nurse; a dentist; two auxiliary nurses; two community health workers; an occupational therapist, who is part of the mental health team; one gynecologist and a pediatrician. In addition to the team responsible for the territory, other professionals are involved in the construction of the work process, namely: a psychologist, a nurse with administrative duties, the management collegiate, the local health council and the local administration. These professionals attend approximately 11,000 persons and, in addition to the monitoring in the unit, offer home visits and health promotion activities in the territory.

The specialist team for the prison addressed the assistance for the women by sharing the medical, dentistry and nursing resources, which were gradually systematized in this team, as were the other professionals and nuclei involved in the process.

The present report was based on the experience of one of the authors who works as a UBS coordinator, but who also participated in some prenatal care provided to the pregnant women in prison, as she is a nurse-midwife, as well as engaging in dialog with the prison service in the construction of the assistential proposals, in accordance with the needs listed by the prison. Other sources of information used were the 
books of records of attendance given for this specific population, containing data such as: date of the attendance, the recording only of the patient's initials, the number of the local hospital record, vaccination and use of tobacco. Data from the hospital records were not used, and no interviews were undertaken with the patients or professionals of the UBS. Furthermore, no data allowing the identification of the pregnant women or the professionals is reported in this article.

It is worth noting that the present experience report will form part of a Masters dissertation on the experience of pregnant women in prison, approved by the Ethics Committee of the Penal Administration Department - São Paulo (SP) under protocol N. $049 / 2011$.

\section{Results}

The attendance was reorganized so as to contribute to the care for the incarcerated women, with the scheduling of medical, dentist and nursing consultations as well as other assistential activities. When necessary, referrals were made to the secondary and tertiary levels of care.

The assistance provided to the prisoners was systematized by the Family Health Team (ESF, in Portuguese) and other workers from the Primary Healthcare Center in the following way: fixed days and times for attendance were reserved in the local schedules. The penitentiary defined, by internal criteria, which pregnant women would be attended on the dates scheduled. As a result, neither the detainees nor the UBS team knew the day and time of the consultations, for reasons of security and availability of an escort and transport.

The attendance on the day was organized based on the medical and nursing consultations. The dental appointments were undertaken in accordance with the prison's requirements and did not necessarily occur on the same date as the prenatal consultation.

The professional nurse was the person responsible for the pregnant woman's first consultation in the center, in which she set up the local health records, the record on the Pre-Natal Health Information System (SIS, in Portuguese) and requested laboratory tests in accordance with the UBS' protocols. Occasionally she undertook a prenatal consultation among pregnant women of up to 32 weeks, alternating with the gynecologist. The nurse was responsible for facilitating contact between the specialist team and the penitentiary and organization of attendance schedules. In some specific situations, she was in the prison, undertaking vaccination campaigns and health promotion activities.

In the prenatal consultations, the pregnant women were attended in a gynecological examination room, always under escort. In accordance with the current municipal protocols, laboratory tests and image studies were made in specialized services. The prisoners waited for the attendance accompanied by a police escort and prison officers, in the health center's common areas, without significant changes in the latter's dynamics.

From two to four appointments were held per day, scheduled twice per week and attending approximately 20 pregnant women per month. This number did not change on holidays or bank holidays, as there was reorganization of schedules so as to guarantee the attendance. Problems with transporting and escorting the detainees stopped some consultations from being held. Where possible, these were rescheduled.

All the pregnant women sent by the women's prison team were referred as priority, and monitored, irrespective of the gestational age, as were women sent for important gynecological treatment. Some pregnant women received dental care. In the event of labor and/or complications, the women were immediately taken to the hospital service.

In the period in question, the presence of comorbidities, drug addiction, sexually transmitted diseases (STD, in Portuguese)) and symptoms of depression were observed. Eating disorders also stood 
out, with repercussions in the pregnant women's weight gain. It is also worth noting the high rate of smokers, including among those who were pregnant. The pregnant women received treatment for health problems besides the prenatal attendance, apart from monitoring in mental health, as the psychiatrist left the service at that time.

As this period progressed, it was necessary to reorganize the work process, in accordance with the difficulties which appeared. The times for transport were not fixed; in some situations, the escort service was not available; it was necessary to adapt the professionals' schedule in accordance with the penitentiary's schedule, as well as the scheduling of other services on the same day as the consultations, such as imaging tests, vaccination and dental treatment, so as to optimize the attendances. The monitoring offered sought to be comprehensive, and included the secondary and tertiary level of health care through the referrals to the specialist and hospital services, when necessary.

During this period, in the UBS' routine meetings, such as the Collective Health Nucleus, Nursing Meetings, Mental Health Team Round Table Meetings and Specialist Team Discussions, the professionals reported lack of preparation for dealing with this specific demand and for appropriately meeting the needs and expectations of the pregnant women in prison. This reflection occurred through the recognition of the risks to physical and mental health within the prison environment and the scarcity of the minimum resources for meeting the basic health needs, which range from structural conditions, nutrition and violence through to the access to health care.

\section{Discussion}

Studies demonstrate that the poor quality of the physical conditions offered in the prisons and jails, the shortage of spaces and the absolute unhealthiness in the prison contribute to the falling-ill of the prison population ${ }^{(15)}$. The cycle involving pregnancy, birth and the puerperal period causes systemic and psychological transformations in women, and is a unique time in which all of the changes occur based on individual, cultural, relational and other factors. The pregnant inmates, therefore, need differentiated care, due to the unfavorable conditions faced in jail, and their particular circumstances. The provision of care to imprisoned pregnant women, principally by the nursing professionals, must recognize sociocultural factors and those intrinsic to this condition, which is different from any other, in order to be able to provide effective care ${ }^{(3)}$.

Our experience is close to that found in North American studies, in relation to the impossibility of providing adequate care, according to established practices and standards, in the penitentiaries, as, for example, in nutritional guidance for a healthy pregnancy and adequate rest, a great effort being necessary for meeting this population's health needs. This context can place the result of the pregnancy at risk, considering that the minimum necessary for ensuring the safety of the mother-child binomial is not offered $^{(16)}$.

Assisting the detainees in the UBS in question made it possible to gain an understanding regarding the care needs, which surpasses our knowledge and practice. Based on the clinical contact with the service users, it became possible to partake in a world hitherto unknown, which described to us how intense the needs encompassing their physical and mental health are. It also evidenced the need to seek specific training for meeting these demands effectively.

The inmates assisted presented the use of psychoactive substances, chronic diseases and STDs, as well as symptoms of depression; that is, a variety of health needs, for the recovery and maintenance of a healthy mind and body. It is not established whether the condition of imprisonment produces or worsens threats to pregnant women's health, but it is clear that there is a need to assist them comprehensively, contributing to the re-establishment of their health 
and, possibly, their social rehabilitation.

North American countries, concerned with the health care for drug addicts, for example, offer programs for managing and treating pregnant women who use psychoactive substances, including pregnant women in prison, such as the MOMS Plus (a public health program for pregnant women who use drugs); this program proposes to treat the use of substances, reduce recidivism, and achieve better results in the pregnancy, encouraging the prenatal monitoring(17). Perhaps similar programs could be implanted in Brazil too.

The prison environment is not familiar to the health professional, because he does not receive training to work in this place during his professional training. We cannot, however, shy away from assisting this population, which is subject to health risks, and which, despite being incarcerated, maintains constant contact with the outside world, whether through the visits received from friends and relatives, or through the staff working in the prison system -which is also a factor to be considered when one thinks about transmissible diseases. These factors point to a serious public health problem, as the lack of health monitoring in the prison system produces an increase and a worsening of illness to which we are exposed in our daily life $\mathrm{e}^{(5-15)}$.

It is necessary for there to be broadening in the effectiveness of the actions for health promotion and recovery and prevention of health problems directed at the prison population, helping to change the current pattern of morbidity and mortality. Understanding this population's real needs can raise the health professionals' awareness and foster public policies capable of meeting said needs; in this way, we will be preparing to face the new challenges which are, at all times, on both Brazil's public health agenda and on the health professional's agenda.

As the limitations in this field of work are great in number, it is necessary for there to be intersectorial and interdisciplinary plans, organized in a network, so as to meet this demand. In this way, it is worth noting that the path to be followed is long, for the care given to be efficacious and to ensure health to the population and, principally, to these groups with specific needs, specific to the context in which they live - in this case, the prison situation.

\section{Final Considerations}

This experience leads us to place responsibilities and expectations in the participation of the government and of management at all its levels for the construction of proposals, creating new alternatives and the broadening of existing resources, so as to reduce the barriers facing citizens regarding access to health and health treatment.

The exposure of convicts, principally women, to illness needs to be interrupted, through proposals which respond to the reduction of violence, and through attendance to the basic needs.

It is considered essential for there to be conditions such that services may be offered comprehensively to the most vulnerable populations, in accordance with the SUS directives. It is necessary to understand that permitting access is not sufficient to meet this population's needs, as, besides the scarcity of resources and the difficulties which are specific to the condition of imprisonment, the identification of the needs and of the aspects of vulnerability occur from the perspective of the professional who assists the detainees and, therefore, may not meet the demands perceived by the service users, which broadens the assistential gaps to the individual deprived of liberty.

The considerable increase in imprisoned women, many of them pregnant, should arouse in us - health professionals, especially nurses - reflections for the seeking of solutions through continuous education and research involving this population. Perhaps answers shall be found indicating a path to the reduction of harm, social reinsertion, and new life histories.

It is hoped that this report may arouse in the health teams confidence and the desire to experience 
this challenging opportunity to care, as well as the search for knowledge through research for the qualification of the assistance provided to people who are imprisoned. Furthermore, it is necessary to allow this population a voice, increasing their right to health!

\section{Collaborations}

Fochi MCS contributed to the conception, editing, critical analysis and final approval of the information to be published. Silva ARC and Lopes MHBM contributed to the critical analysis, editing and final approval of the version to be published.

\section{References}

1. Araújo NM, Salim NR, Gualda DMR, Silva LCFP. Body and sexuality during pregnancy. Rev Esc Enferm USP. 2012; 46(3):552-8.

2. Santos AL, Radovanovic CAT, Marcon SS. Assistência pré-natal: satisfação e expectativas. Rev Rene. 2010; 11(n.esp):61-71.

3. Rodrigues EM, Nascimento RG, Araújo A. Prenatal care protocol: actions and the easy and difficult aspects dealt by Family Health Strategy nurses. Rev Esc Enferm USP. 2011; 45(5):1041-7.

4. Nicolau OIA, Ribeiro GS, Lessa ARP, Monte SA, Ferreira NCR, Pinheiro BKA. A picture of the socioeconomic and sexual reality of women prisoners. Acta Paul Enferm. 2012; 25(3):386-92.

5. Canazaro D, Argimon LII. Características, sintomas depressivos e fatores associados em mulheres encarceradas no Estado do Rio Grande do Sul, Brasil. Cad Saúde Pública. 2010; 26(7):1323-33.

6. Scherer PAZ, Scherer AE, Nascimento DA, Ragozo DF. Perfil sociodemográfico e história penal da população encarcerada de uma penitenciária feminina do interior do estado de São Paulo. SMAD Rev Eletr Saúde Mental Álcool Drog [periódico na Internet]. 2011 [citado 2013 jul 12]; 7(2): 5562. Disponível em: http://www2.eerp.usp.br/ resmad/artigos/SMAD_v7_n2_a_02.pdf
7. Merhy E. Saúde e direitos: tensões de um SUS em disputa, molecularidades. Saúde Soc. 2012; 21(2):267-79.

8. Brasil. Lei $n^{\circ}$ 8.080, de 19 de setembro de 1990. Dispõe sobre as condições para a promoção, proteção e recuperação da saúde, a organização e o funcionamento dos serviços correspondentes e dá outras providências. Diário Oficial da União, Brasília, 20 set. 1990; Seção 1:018055.

9. Ministério da Saúde (BR). Secretaria Nacional de Assistência à Saúde. ABC do SUS- doutrinas e princípios. Brasília: Ministério da Saúde; 1990.

10. Ministério da Saúde (BR). Secretaria de Atenção á Saúde. Departamento de Atenção Básica. Política Nacional de Atenção Básica. Brasília: Ministério da Saúde; 2006.

11. Ministério da Saúde (BR). Legislação da saúde no sistema penitenciário. Brasília: Ministério da Saúde; 2010 (Série E. Legislação de Saúde).

12. Ministério da Justiça (BR). Sistema Prisional InfoPen [Internet]. [citado 2013 jun 23]. Disponível em: www.mj.gov.br/DEPEN

13. Instituto Brasileiro de Geografia e Estatística (IBGE). Censo demográfico: resultados finais [Internet]. 2012 [citado 2013 jul 11]. Disponível em: http://cidades.ibge.gov.br/xtras/perfil. php?lang=\&codmun $=350950$

14. Campos SWG, Ferrer LA, Corrêa CRS, Madureira PR, Gama CAP, Dantas DV, et al. Avaliação de Estratégias Inovadoras na Organização da Atenção Primária à Saúde. Rev Saúde Pública. 2012; 46(1):43-50.

15. Gois SM, Santos Júnior HPO, Silveira MFA, Gaudêncio MMP. Para além das grades e punições: uma revisão sistemática sobre a saúde penitenciária. Ciênc Saúde Coletiva. 2012; 17(5):1235-46.

16. Fersz GG, Clarke JG. Health care of pregnant women in U.S. state prisons. J Health Care Poor Underserved. 2012; 23(2):557-69.

17. Lorenzen D, Bracy K. MONS Plus: A public health program for substance using pregnant inmates in an urban jail. J Correct Health Care. 2011; 17(3):233-40. 